\title{
Assessment of the Impacts of Global Climate Change and Regional Water Projects on Streamflow Characteristics in the Geum River Basin in Korea
}

\author{
Soojun Kim ${ }^{1}$, Huiseong Noh ${ }^{2}$, Jaewon Jung ${ }^{3}$, Hwandon Jun ${ }^{4}$ and Hung Soo Kim ${ }^{5, *}$ \\ 1 Columbia Water Center, Earth Institute, Columbia University, New York, NY 10027, USA; \\ soojun78@gmail.com \\ 2 Department of Water Resources Research Division, Korea Institute of Civil Engineering and Building \\ Technology (KICT), Goyang 10223, Korea; heesung80@hanmail.net \\ 3 Department of Safety and Environment Research, Seoul Institute, Seoul 137-071, Korea; \\ jungjw89@gmail.com \\ 4 Department of Civil Engineering, Seoul National University of Science and Technology, Seoul 139-743, \\ Korea; hwjun@snut.ac.kr \\ 5 Department of Civil Engineering, Inha University, Incheon 402-751, Korea \\ * Correspondence: sookim@inha.ac.kr; Tel.: +82-32-860-7572; Fax: +82-32-876-9783
}

Academic Editor: Ashantha Goonetilleke

Received: 21 December 2015; Accepted: 3 March 2016; Published: 8 March 2016

\begin{abstract}
The impacts of two factors on future regional-scale runoff were assessed: the external factor of climate change and the internal factor of a recently completed large-scale water resources project. A rainfall-runoff model was built (using the Soil and Water Assessment Tool, SWAT) for the Geum River, where three weirs were recently constructed along the main stream. RCP (Representative Concentration Pathways) climate change scenarios from the HadGEM3-RA RCM model were used to generate future climate scenarios, and daily runoff series were constructed based on the SWAT model. The indicators of the hydrologic alteration (IHA) program was used to carry out a quantitative assessment on the variability of runoff during two future periods (2011-2050, 2051-2100) compared to a reference period (1981-2006). Analyses of changes in the runoff characteristics of the lower Geum River showed that climate change is likely to lead to an increase of the future runoff ratio and that weirs contributed to an increase in the minimum discharge and a decrease in the maximum discharge. The influence of the weirs on the runoff characteristics of the Geum River basin was projected to be greater than that of climate change.
\end{abstract}

Keywords: climate change; water projects; streamflow; water resources

\section{Introduction}

People have inhabited places close to rivers or lakes to ensure water supply for several purposes, including as a source of water for domestic, industrial, and agricultural purposes, a means of power generation and waste disposal, routes for navigation, and sites for recreation and spiritual activities [1,2]. Global climate change influences hydro-meteorological characteristics, including both spatio-temporal and quantitative changes. According to the Synthesis Report of the Intergovernmental Panel on Climate Change (IPCC) Fourth Assessment Report [3], global warming is clearly evidenced by the rise of the earth's average temperature and sea water temperature, widespread melting of snow and glaciers, and the rise of the earth's sea level, which has been observed and measured. Quantitative fluctuations of water resources have been aggravated because of the impacts of climate change; as a result, droughts and floods have become more frequent throughout the world, causing huge human and property damage, and more intense natural disasters are expected to occur in the future [4]. 
Many researchers have evaluated the changes in runoff characteristics due to climate change; they have developed water balance models and applied their models to different regions to explore the impacts of climate change. For example, Gleick [5] applied his model to the Sacramento Basin, and Yates and Strzepek [6] and Guo, et al. [7] performed similar studies for the Nile River of Egypt and for China, respectively. To explore the impacts of climate change and urbanization upon runoff characteristics, Franczyk and Chang [8] performed continuous runoff simulations using AVSWAT-X for a highly and rapidly urbanized area. Cuo, et al. [9] considered the simultaneous impacts of the mid-21st century climate and land cover changes on the hydrology of the Puget Sound basin. Purkey, et al. [10] applied the Water Evaluation and Planning System (WEAP) model to the Sacramento River Basin and confirmed its applicability. Obeysekera, et al. [11] took climate change into account when analyzing flood control and the vulnerability of the water management system in south Florida. Some studies $[8,12]$ have been conducted to estimate the impacts of climate change and land-use change on runoff characteristics. Qiao, et al. $[13,14]$ evaluated the hydrologic response of the trans-state Oologah Lake watershed to climate change by using both statistically and dynamically downscaled multiple climate projections, and also evaluated the hydrological change and uncertainty in the lower Missouri River Basin under climate change. Most climate change-related studies predict that natural disasters, such as droughts and floods, will occur more powerfully and frequently in the future owing to more extreme meteorological phenomena.

The increasing concern regarding climate change has brought about global climate change adaptation efforts. In line with this, South Korea recently carried out the Four Rivers Restoration Project as a strategy to actively respond to climate change. The goal of the Four Major Rivers Restoration Project of South Korea was to restore the Han, Nakdong, Geum, and Yeongsan Rivers and to provide water security, flood control, and ecosystem vitality [15]. The project cost 22.2 trillion won (approximately 17.3 billion USD) and was completed in October 2011. The project's main aims in terms of hydrological processes were to secure sufficient water volume by creating an additional stored water volume of 1.3 billion $\mathrm{m}^{3}$, and to prepare coordinated measures for flood control by providing an additional flood-control capacity of 0.92 billion $\mathrm{m}^{3}$ [15]. Sixteen small, multipurpose dams (weirs) were built to control flows in the four rivers; these dams were each 300-600 m long and 4-12 $\mathrm{m}$ in height, and were installed in dredged river sections: three in the Han River, eight in the Nakdong River, two in the Yeongsan River and three in the Geum River.

Because both climate change and water resources projects can affect a river's runoff characteristics, this study considered both impacts, unlike previous studies that focused only on applying climate change scenarios to the analysis. Specifically, this study included considerations of the impacts of both global climate change and hydraulic structures built to improve the availability of local water resources, to analyze the resulting changes in projected future runoff characteristics. To this end, by using a rainfall-runoff model that could include the influence of weirs, future runoff was estimated in this study based on climate change scenario data as input data. This study was also focused on evaluating changes in the runoff characteristics during future target periods. In addition, quantitative analyses of the changes in future runoff characteristics were conducted by using IHA software.

The study is organized as follows: Section 2 introduces the data and methodology used in this study to consider climate change. Section 3 discusses the application of SWAT to the runoff analysis of the Geum River and presents modeling results; additionally, the characteristics of runoff changes are quantitatively evaluated based on IHA, and the major results of the analysis are discussed. Finally, in Section 4, findings are summarized and conclusions are presented.

\section{Materials and Methodology}

\subsection{Climate Model and Scenarios}

The National Institute of Meteorological Research (NIMR) of Korea is participating in the Coordinated Regional Climate Downscaling Experiment (CORDEX) with the Regional Climate 
Model (RCM) HadGEM3-RA, which is based on the global atmospheric model HadGEM3 of the Met Office Hadley Centre (MOHC). The configuration of HadGEM3-RA is almost the same as that of HadGEM3-A, except that the dynamic settings are taken from the operational limited-area model. Detailed descriptions of the dynamics core and physical packages are given in Davies et al. [16] and Martin et al. [17]. The configuration of the model domain follows the protocol of the CORDEX for Asia [18]. In this study, we used downscaled RCM and two RCP (Representative Concentration Pathways) scenarios (4.5 and 8.5) for the Eastern Asia region provided by NIMR (See Table 1).

Table 1. NIMR climate change scenario data.

\begin{tabular}{cc}
\hline Model & HadGEM3-RA \\
\hline Scenarios & RCP 4.5, 8.5 \\
\hline Time period & $1950-2100$ \\
\hline Grid size & $12.5 \mathrm{~km}$ \\
\hline Meteorological factor & $\begin{array}{c}\text { Temperature (maximum, minimum, average), precipitation, near-surface } \\
\text { wind speed, surface upwelling longwave radiation, surface downwelling } \\
\text { shortwave radiation, surface air pressure, near-surface specific humidity }\end{array}$ \\
\hline Time scale & Daily average, monthly average \\
\hline
\end{tabular}

\subsection{Bias Correction by Using Quantile Mapping}

Downscaled results from GCMs (General Circulation Models) tend to show some level of bias against real observed outcomes. The most commonly used method to correct such bias is quantile mapping, suggested by Panofsy and Brire [19]. The quantile mapping approach has been used as a way to correct runoff [20,21], and in regard to climate change, GCM data in Palmer et al. [22], Durman et al. [23], and Kyoung et al. [24]. The general procedure of quantile mapping is illustrated schematically in Figure 1. It is an empirical statistical technique that matches the quantile of a simulated value to the observed value at the same quantile as shown in Figure 1.

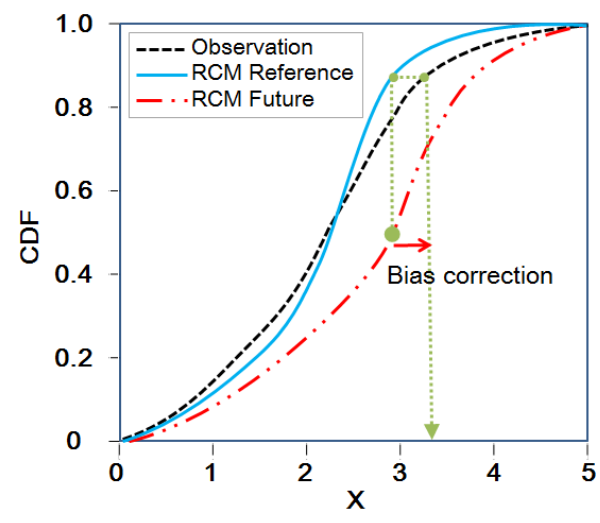

Figure 1. Quantile mapping for bias correction.

Quantile mapping bias correction is a common method to use the output of GCMs or RCMs on a local scale. Maurer et al. [25] and Cannon et al. [26] demonstrated that it can modify the projected changes, or trends, produced by climate models. Maurer et al. [27] suggested the need for stochastic bias correction to overcome these problems. Many stochastic bias correction methods have been developed [28-32], but producing actual reproductions of the hydrological process using these methods continues to be a challenge. Runoff in a basin can be accurately assessed only when the temporal correlation among the weather variables is preserved at each site, which must be analyzed in relation with the spatial correlation among each site in the basin. The quantile mapping approach was used 
in this study to estimate the bias between observed data and the RCM, with respect to both the monthly total precipitation of reference period scenarios, and that of in situ stations operated by the Korea Meteorological Administration (KMA). Then, the results were applied to RCP 4.5 and RCP 8.5 projection periods to correct the daily total precipitation bias for each period. It has better ability to preserve the correlations among weather variables, such as precipitation, temperature, humidity, wind velocity and solar radiation, although it has weaknesses in representing the output of the RCM.

\subsection{SWAT for Runoff Simulation}

SWAT is a physically based, distributed, agro-hydrological model that operates on a daily time step (as a minimum) at the watershed scale. SWAT is designed to predict the impact of management upon water, sediment, and agricultural chemical yields in ungauged catchments [33]. The model is capable of continuous simulation of dissolved and particulate elements in large complex catchments with varying weather, soils, and management conditions over long periods of time. SWAT can analyze small or large catchments by discretizing them into subbasins, which are then further subdivided into hydrological response units with homogeneous land use, soil type, and slope. When embedded within a geographical information system (GIS), SWAT can integrate various spatial environmental data including soil, land cover, climate, and topographical features. Theory and details on the hydrological and sediment transport processes integrated in SWAT are available online in the SWAT documentation [34].

In this study, the weirs of the Geum River were considered as a reservoir factor in SWAT. During the flood season, water is discharged through the principal spillway and the emergency spillway, whereas during the non-flood season, water is discharged and obtained from the storage capacity (the minimum discharge volume is set) as shown in Figure 2. The Target Release for Controlled Reservoir method [35] was applied as the reservoir operation method.

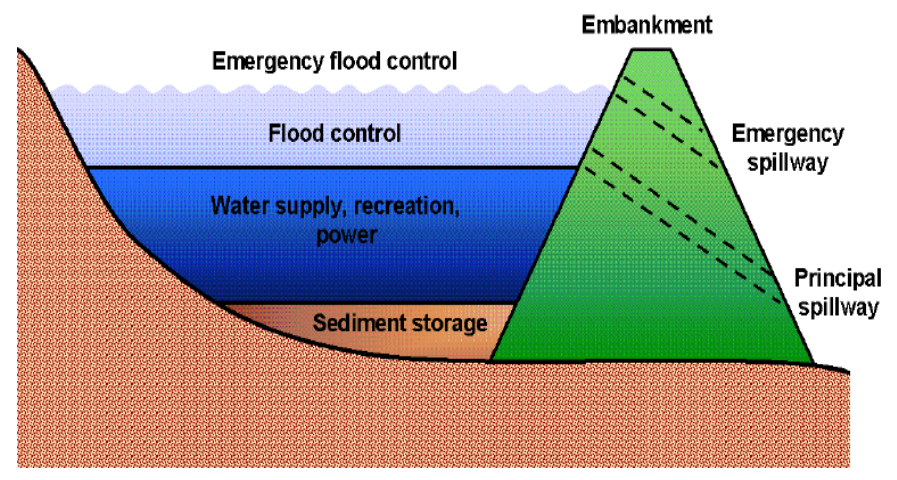

Figure 2. Components of a reservoir with flood water detention features [36].

For the target release approach, the principal spillway volume corresponds to the maximum flood control reservation and the emergency spillway volume corresponds to the no flood control reservation.

\subsection{Indicators of Hydrologic Alteration to Assess the Runoff Characteristics}

Richter et al. [37] developed the IHA program to assess the degree to which human disturbance affects hydrologic regimes based on either hydrologic data available for a specific ecosystem or model-generated data. Richter, et al. [38] applied IHA and proposed the range of variability approach (RVA) with the aim of setting streamflow-based river management targets that incorporate the concepts of hydrologic variability and aquatic ecosystem integrity.

IHA employs 33 parameters, which are categorized into five groups based on their magnitude, timing, frequency, duration, and rate of change. Parameter group 1 comprises 12 monthly median flows representing normal flow conditions. Parameter group 2 comprises 10 parameters describing 
the magnitude and duration of annual extreme flows: 1-, 3-, 7-, 30-, and 90-day annual maxima and minima encompassing the daily, weekly, monthly, and seasonal cycles. The base flow index was obtained by dividing the 7-day minimum flow by the annual mean flow. Parameter group 3 comprises the two Julian dates of the 1-day annual maximum and minimum, indicating the timing of annual extreme flows. Parameter group 4 comprises four parameters indicating the frequency and duration of the high and low pulses; the high pulses are periods within a year when the daily flows are above the 75th percentile daily flow of the pre-impact period, and the low pulses are periods within a year when the daily flows are below the 25th percentile daily flow of the pre-impact period [36]. Parameter group 5 comprises three parameters (fall rate, rise rate, and number of reversals) indicating the numbers and mean rates of both positive and negative changes in flow within two consecutive days.

When analyzing the change between two time periods, the RVA [38] is very useful. In an RVA analysis, the full range of pre-impact data for each parameter is divided into three different categories. The boundaries between categories are based on either percentile values (for nonparametric analysis) or on a number of standard deviations away from the mean (for parametric analysis). For nonparametric RVA analysis, Richter et al. [39] proposed a simple three-class evaluation system for individual IHA. The hydrologic alteration (HA) is expressed as follows:

$$
\mathrm{HA}[\%]=(\text { observed frequency }- \text { expected frequency }) / \text { expected frequency }
$$

where the observed frequency is defined as the number of years wherein the observed value of the hydrologic parameter falls within the targeted range and the expected frequency is defined as the number of years wherein the value is expected to fall within the targeted range.

\section{Application and Results}

\subsection{Study Basin}

The Geum River basin is the third largest river basin in Korea, and is situated on the west-central part of the Korean peninsula. It occupies an area of $9835.3 \mathrm{~km}^{2}$, almost one tenth of Korea, and ranges about $130 \mathrm{~km}$ east to west and about $160 \mathrm{~km}$ north to south. The total length of the main stream of the Geum River is $395.9 \mathrm{~km}$ and two large multipurpose dams, Yongdam and Daechung reservoirs, exist in the upper and lower regions of the Geum River basin, respectively, as shown in the digital elevation model given in Figure 3.
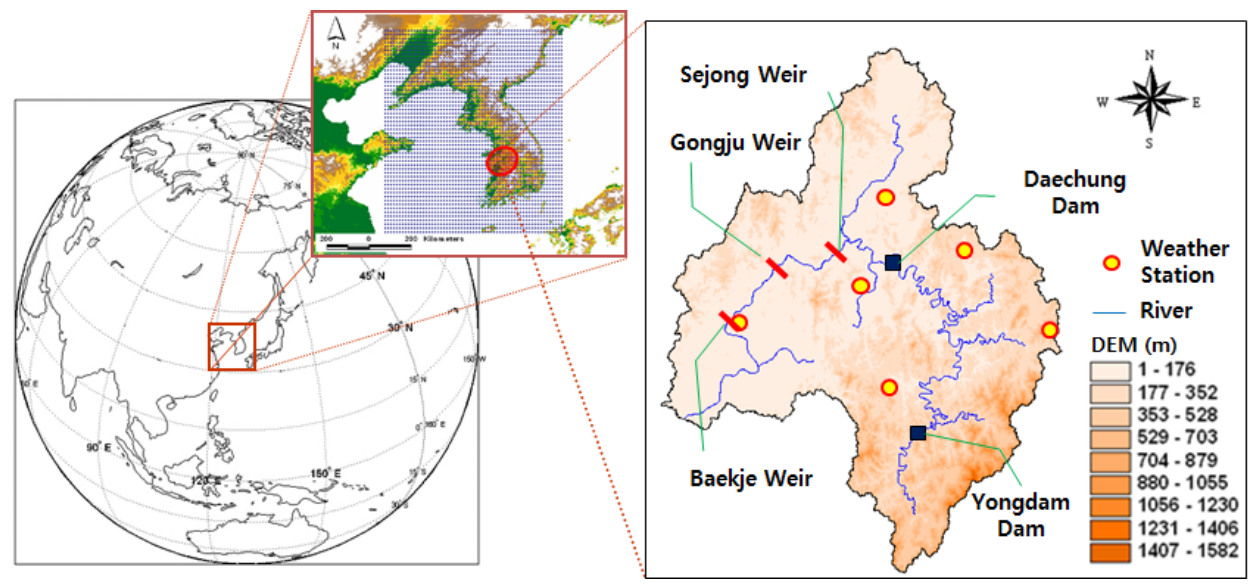

Figure 3. Study area (Geum River basin).

Daily weather observation data (daily minimum and maximum air temperature, relative humidity, wind speed, and solar radiation) is collected at six weather stations, namely, the Cheongju, Daejeon, Chupung, Boeun, Buyeo, and Geumsan stations; Table 2 lists the stations' locations. 
Table 2. Weather stations in the Geum River basin.

\begin{tabular}{|c|c|c|c|c|}
\hline Name & Latitude $\left({ }^{\circ}\right)$ & Longitude $\left({ }^{\circ}\right)$ & Elevation (m) & Meteorological Data \\
\hline Cheongjoo & 36.6364 & 127.4428 & 57.4 & \multirow{6}{*}{$\begin{array}{l}\text { Min. air temperature } \\
\text { Max. air temperature } \\
\text { Relative humidity } \\
\text { Wind speed } \\
\text { Solar radiation } \\
\text { (Daily, 1981-2006) }\end{array}$} \\
\hline Daejeon & 36.3691 & 127.3743 & 68.3 & \\
\hline Chuphung & 36.2171 & 127.9965 & 242.5 & \\
\hline Boeun & 36.4848 & 127.7363 & 170 & \\
\hline Buyeo & 36.2694 & 126.923 & 16 & \\
\hline Geumsan & 36.1027 & 127.4838 & 170.7 & \\
\hline
\end{tabular}

As part of the Four Major Rivers Restoration Project, three weirs (Sejong, Gongju, and Baekje weirs) were built in the lower Geum River in 2011; Table 3 lists details for each weir. According to the Ministry of Land, Transport and Maritime Affairs in Korea [40], the additional storage capacities of the Sejong, Gongju, and Baekje weirs were $1.3 \times 10^{6} \mathrm{~m}^{3}, 10.4 \times 10^{6} \mathrm{~m}^{3}$, and $18.1 \times 10^{6} \mathrm{~m}^{3}$, respectively.

Table 3. Design data on the Geum River weirs [29].

\begin{tabular}{ccccccc}
\hline Weir & $\begin{array}{c}\text { Weir Height } \\
(\mathbf{m})\end{array}$ & $\begin{array}{c}\text { Water Level } \\
\mathbf{( E L . m )}\end{array}$ & $\begin{array}{c}\text { Average } \\
\text { Depth } \mathbf{( m )}\end{array}$ & $\begin{array}{c}\text { Surface Area } \\
\left.\mathbf{( 1 0}^{\mathbf{6}} \mathbf{~ m}^{\mathbf{2}}\right)\end{array}$ & $\begin{array}{c}\text { Increased } \\
\text { River Width } \\
(\mathbf{m})\end{array}$ & $\begin{array}{c}\text { Increased } \\
\text { Storage Volume } \\
\left(\mathbf{1 0}^{\mathbf{6}} \mathbf{~ m}^{\mathbf{3}} \mathbf{)}\right.\end{array}$ \\
\hline Sejong & 4 & 11.4 & 2.1 & 3.0 & 72 & 1.3 \\
Gongju & 7 & 8.8 & 4.2 & 4.7 & 78 & 10.4 \\
Baekje & 7 & 4.2 & 4.6 & 6.8 & 131 & 18.1 \\
\hline
\end{tabular}

\subsection{Runoff Simulation}

Because both the global factors of climate change and the large hydraulic structures located along the main stream are projected to change the future runoff characteristics of the Geum River basin, a runoff model was built for the river basin by using SWAT. Maps of 1:25,000 scale were collected to generate a $100 \times 100 \mathrm{~m}^{2} \mathrm{DEM}$ and the river network. Furthermore, the major dams (Daecheong Dam and Yongdam Dam) and the three weir points (Sejong, Gongju, and Baekje weirs) in the river basin were added to the reservoir factors. To implement the weirs as a reservoir factor, the additionally secured storage capacities from the newly built weirs were assumed as the reservoir capacity in SWAT. In addition, it was assumed that the reservoirs were operated to retain the reservation volume target corresponding to the Normal High Water Level and thus the Target Release for Controlled Reservoir, which is the reservoir operation method of SWAT that was selected and applied. The legal in-stream flow volume for each weir point (Sejong $12.8 \mathrm{~m}^{3} / \mathrm{s}$, Gongju $15.1 \mathrm{~m}^{3} / \mathrm{s}$, and Baekje $17.1 \mathrm{~m}^{3} / \mathrm{s}$ ) was set as the minimum discharge. In addition, a land cover map (Figure $4 \mathrm{~b}$ ) and a soil map (Figure 4c) from the National Water Resources Management Information System (WAMIS) [41] were used. The Geum River basin was classified into eight different land use conditions, among which forest $(61.2 \%)$ and rice paddy $(19.8 \%)$ accounted for $80 \%$ of the land use. The soil map, which included classifications of eight types of soil texture, showed that "Loam $(60.9 \%)$ " and "Clay loam $(9.4 \%)$ " were the most prevalent soil types in the area. Based on the above data, GIS data were prepared to generate hydrological response units to build the model used for study.

In this study, surface runoff was estimated using the Soil Conservation Service Curve Number. Any water that does not become surface runoff enters the soil column, where it can be removed by evapotranspiration or by deep percolation into the deep aquifer, or can move laterally in the soil column as a streamflow contribution. Groundwater contribution to streamflow can be generated from shallow and deep aquifers and is based on the groundwater balance. The Penman-Monteith method [42] was used to estimate evapotranspiration.

To calibrate and validate the model, daily discharge data for the 26-year period from 1981 to 2006 (26 years) were acquired from the Daecheong and Gyuam sites. The calibration and validation 
periods were classified as 1995-2001 and 2003-2006, respectively. Data from the 2011-2013 period immediately after the completion of weir construction was additionally collected from the Gyuam site, to understand the applicability of adding the new reservoirs to the model as a means of accounting for the impacts of the newly built weirs (2008-2011) on the river basin. The results of model calibration and validation are shown in Figure 5 (results from the Gyuam site only) and Table 4. Although the model seems to underestimate the extreme runoff peaks, the evaluation results of the model, which were based on the coefficient of correlation (CC), coefficient of determination $\left(\mathrm{R}^{2}\right)$, model efficiency $(\mathrm{ME})$, and root mean squared error (RMSE), indicated that the model properly represented the runoff characteristics of the Geum River basin : the coefficient of correlation was $0.75-0.79$, the coefficient of determination was $0.56-0.62$, the model efficiency was $0.49-0.56$, and the RMSE was $132-312 \mathrm{~m}^{3} / \mathrm{s}$.

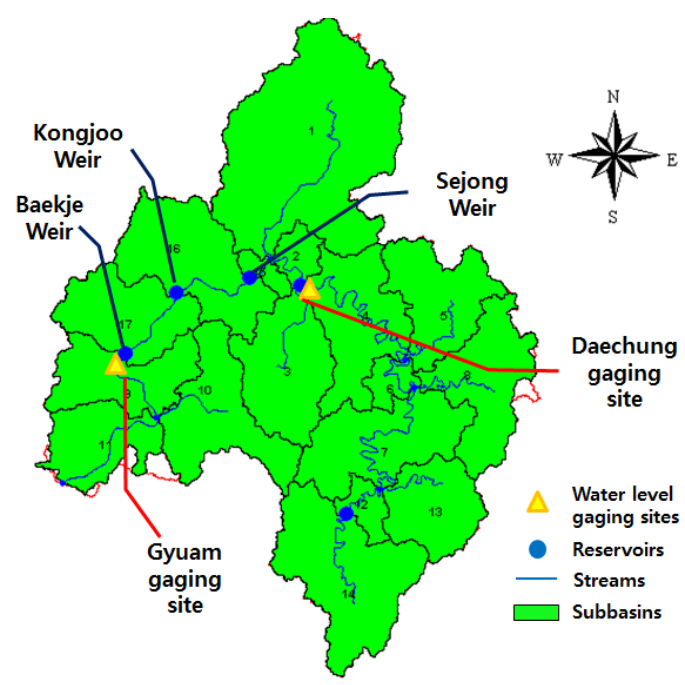

(a)

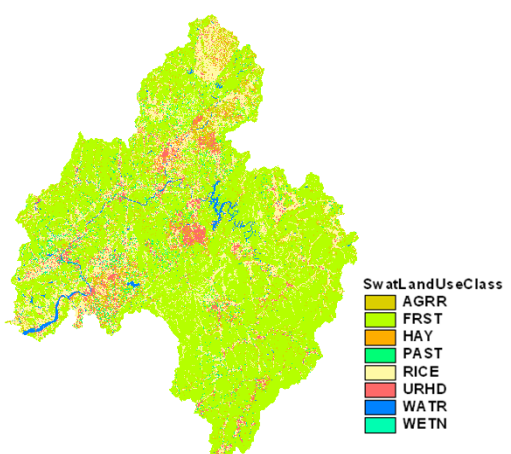

(b)

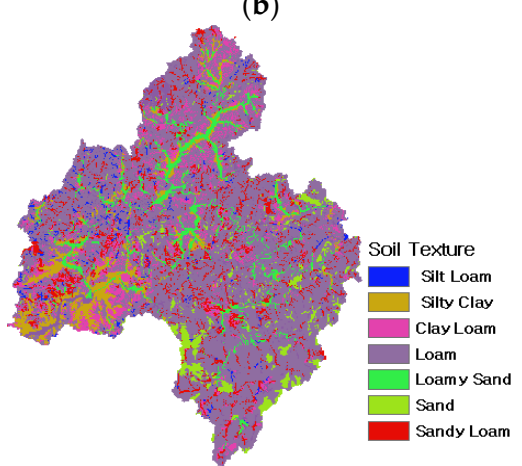

(c)

Figure 4. Geographic Information System (GIS) data as SWAT input. (a) Streams and subbasins; (b) Land use map; (c) Soil type map.

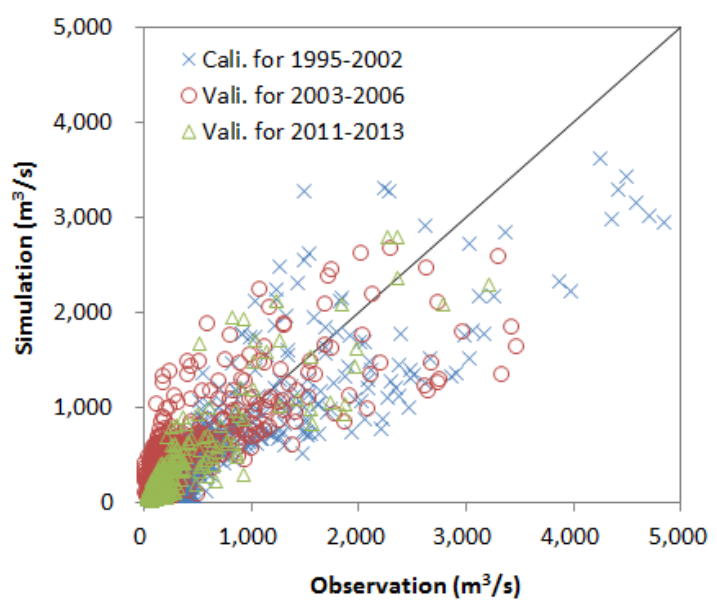

Figure 5. Observed and simulated daily discharge at Gyuam site. 
Table 4. Calibration and validation results of the model for daily discharge data.

\begin{tabular}{cccccc}
\hline & \multicolumn{2}{c}{ Daechung } & Gyuam \\
\cline { 2 - 6 } & $\begin{array}{c}\text { Calibration, } \\
\text { 1995-2002 }\end{array}$ & Validation, & Calibration, & Validation, & Validation, \\
& $\mathbf{2 0 0 3 - 2 0 0 6}$ & $\mathbf{1 9 9 5 - 2 0 0 2}$ & $\mathbf{2 0 0 3 - 2 0 0 6}$ & $\mathbf{2 0 1 1 - 2 0 1 3}$ \\
\hline $\mathrm{CC}$ & 0.79 & 0.77 & 0.78 & 0.75 & 0.75 \\
$\mathrm{R}^{2}$ & 0.62 & 0.59 & 0.60 & 0.57 & 0.56 \\
$\mathrm{ME}$ & 0.53 & 0.49 & 0.56 & 0.55 & 0.52 \\
$\mathrm{RMSE}\left(\mathrm{m}^{3} / \mathrm{s}\right)$ & 153.92 & 185.29 & 202.70 & 312.08 & 132.25 \\
\hline
\end{tabular}

The future daily weather data ( $\mathrm{min}$. air temperature, max. air temperature, relative humidity, wind speed, and solar radiation) were applied, after the errors were calibrated for each weather station (see Table 2) with quantile mapping, from the reference by HadGEM3-RA and the RCP 4.5 and 8.5 scenarios.

For the daily mean precipitation, which is most sensitive to runoff, the application results of the RCP 4.5 and RCP 8.5 scenarios in the Daejeon weather station are shown in Figure 6. For the bias-corrected daily mean (Figure 6a) and the standard deviation (Figure 6b) as the averaged results of the scenarios, the reference showed the characteristics of observation appropriately based on quantile mapping. The future period was classified according to the near term (future 1, 2011-2050) and the far term (future 2, 2051-2100), and the daily mean precipitation was compared to the reference (about $3.7 \mathrm{~cm}$ ); the increase in the far term (about $4.6 \mathrm{~cm}$ ) was greater than that of the near term (about $4.3 \mathrm{~cm}$ ). In this way, the future daily weather series was calculated and used as input data for SWAT.

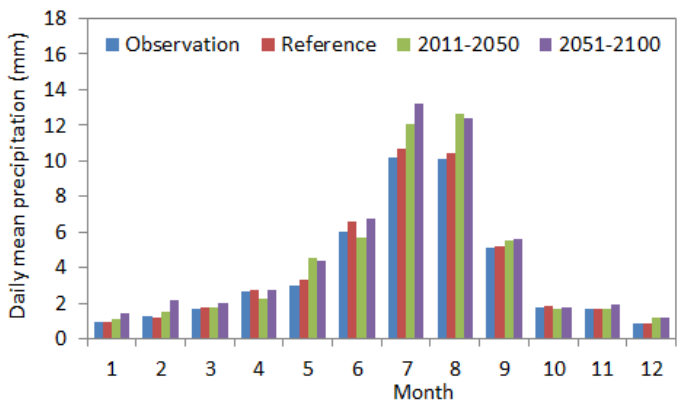

(a)

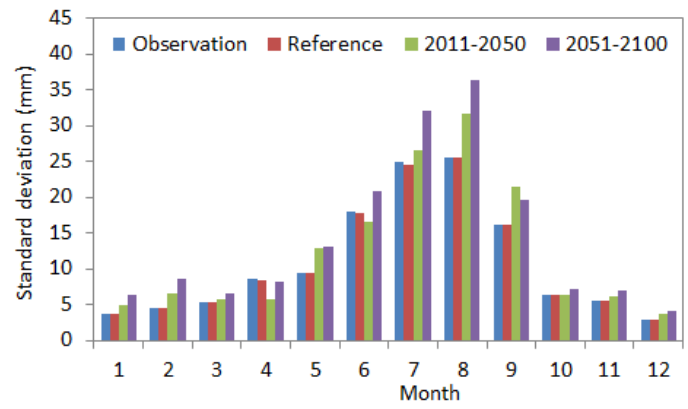

(b)

Figure 6. Daily bias-corrected precipitation of the RCP 4.5 and RCP 8.5 scenarios in each month at the Daejeon weather station. (a) Daily mean precipitation; (b) Standard deviation.

This study focused on two factors to assess future runoff characteristics of the Geum River basin: the impact of climate change and the impact of the newly built weirs. An attempt was made to analyze the impacts comprehensively; Table 5 lists the conditions for the analysis. In addition, the study included a scenario in which the weirs were not built, comparing the runoff characteristics of the future (2011-2100) under RCP 4.5 and RCP 8.5 with those of the reference period (1981-2006). This scenario was included to investigate the extent to which the weirs would influence future runoff characteristics.

Table 5. Five simulation conditions to run the model.

\begin{tabular}{lccccc}
\hline \multirow{2}{*}{ Scenarios } & \multirow{2}{*}{$\begin{array}{c}\text { Reference } \\
\text { (1981-2006) }\end{array}$} & & \multicolumn{2}{c}{ Climate Change (2011-2100) } \\
\cline { 4 - 5 } & & & RCP 4.5 & RCP 8.5 \\
\hline \multirow{2}{*}{ Water project } & No Weir & $\sqrt{ }$ & $\sqrt{ }$ & $\sqrt{ }$ \\
& Weir & - & $\sqrt{ }$ & $\sqrt{ }$ \\
\hline
\end{tabular}


Discharge was simulated based on the conditions needed to run the model, listed in Table 5. The daily discharge series for the Gyuam site, which represents the lower Geum River, is shown in Figure 7. Table 6 summarizes the simulated discharges arising from various simulation conditions for the Gyuam site and compares them to those of the reference period. First, when it was assumed that the weirs were absent, the average and standard deviation of the future runoff ratio (the average of RCP 4.5 and RCP 8.5) increased by $8.7 \%$ and 17.7\%, respectively, in Future 1 (2011-2050), and by $20.8 \%$ and $29.9 \%$, respectively, in Future 2 (2011-2050). On the other hand, when it was assumed that the weirs did exist, the average increased by $10.4 \%$ in Future 1 and by $22.6 \%$ in Future 2, whereas the standard deviation decreased by $7.8 \%$ in Future 1 and by $1.6 \%$ in Future 2. This result shows that because of the projected climate change, both the daily mean runoff and the variability increased; and that the weirs increased daily mean runoff while also reducing its variability.

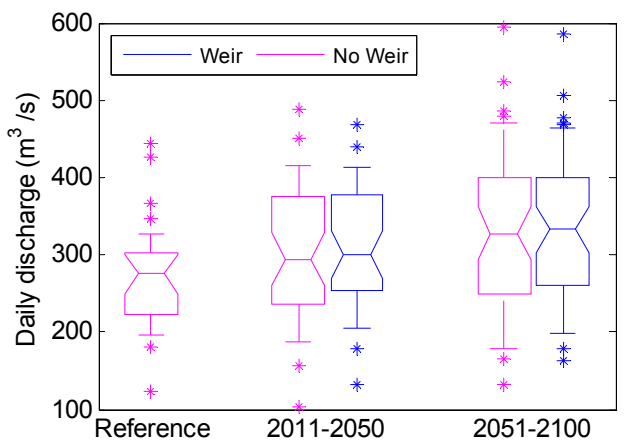

Figure 7. Simulated daily discharge at Gyuam site.

Table 6. Simulation results for the Gyaum site, for various model conditions.

\begin{tabular}{|c|c|c|c|c|c|c|}
\hline \multirow{2}{*}{\multicolumn{2}{|c|}{$\begin{array}{c}\text { Periods } \\
\text { Scenarios }\end{array}$}} & \multirow{2}{*}{$\begin{array}{l}\text { 1981-2006 } \\
\text { Reference }\end{array}$} & \multicolumn{2}{|c|}{ 2011-2050 (Future 1) } & \multicolumn{2}{|c|}{ 2051-2100 (Future 2) } \\
\hline & & & RCP4.5 & RCP8.5 & RCP4.5 & RCP8.5 \\
\hline \multirow{4}{*}{ No Weir } & \multirow{2}{*}{ Average } & \multirow{2}{*}{271.1} & 293.6 & 296.2 & 315.4 & 339.6 \\
\hline & & & \multicolumn{2}{|c|}{$294.9(+8.7 \%)$} & \multicolumn{2}{|c|}{$327.5(+20.8 \%)$} \\
\hline & \multirow{2}{*}{ Standard deviation } & \multirow{2}{*}{371.4} & 431.6 & 442.5 & 424.8 & 540.1 \\
\hline & & & \multicolumn{2}{|c|}{$437.1(+17.7 \%)$} & \multicolumn{2}{|c|}{$482.4(+29.9 \%)$} \\
\hline \multirow{4}{*}{ Weir } & \multirow{2}{*}{ Average } & \multirow{2}{*}{271.2} & 298.5 & 300.3 & 319.7 & 345.5 \\
\hline & & & \multicolumn{2}{|c|}{$299.4(+10.4 \%)$} & \multicolumn{2}{|c|}{$332.6(+22.6 \%)$} \\
\hline & \multirow{2}{*}{ Standard deviation } & \multirow{2}{*}{371.4} & 330.7 & 354.0 & 320.5 & 410.8 \\
\hline & & & \multicolumn{2}{|c|}{$342.4(-7.8 \%)$} & \multicolumn{2}{|c|}{$365.7(-1.6 \%)$} \\
\hline
\end{tabular}

\subsection{Assessment of Future Runoff Characteristics by IHA}

The IHA program provides additional quantitative information on the changes in runoff characteristics of rivers [37,38,43,44]. An analysis tool offered by The Nature Conservancy (IHA Version 7.1, [45]) was used in this study to understand the changes in runoff characteristics of the Geum River arising from the impacts of climate change and weirs. Gyuam was selected as a representative site and the results obtained from the SWAT simulation were used so that IHA could be applied. Based on the nonparametric method, 32 hydrologic parameters were estimated (50\%) according to whether or not the weirs are built for the reference period (1981-2006) and for future periods (the average of RCP 4.5 and RCP 8.5, 2011-2050, and 2051-2100). Hydrologic alteration (HA) was calculated based on Equation (1) and parameter changes were classified into minimal or no alteration $(0 \%-33 \%$, indicated as L), moderate alteration ( $34 \%-67 \%$, indicated as $\mathrm{M})$, and high alteration $(68 \%-100 \%$, indicated as $\mathrm{H})$ groups, according to the levels suggested by Richter et al. (1998). Table 7 summarizes the results. 
Table 7. Changes in indicators of hydrologic alteration (HA) analysis at the Gyuam site.

\begin{tabular}{|c|c|c|c|c|c|c|c|}
\hline \multirow{2}{*}{\multicolumn{2}{|c|}{ IHA }} & \multirow{2}{*}{\multicolumn{2}{|c|}{$\begin{array}{c}\text { Reference } \\
\text { No Weir Value/Unit }\end{array}$}} & \multicolumn{2}{|c|}{ Future 1 (2011-2050) } & \multicolumn{2}{|c|}{ Future 2 (2051-2100) } \\
\hline & & & & $\begin{array}{l}\text { No Weir \% } \\
\text { (HA) }\end{array}$ & $\begin{array}{c}\text { Weir \% } \\
\text { (HA) }\end{array}$ & $\begin{array}{l}\text { No Weir \% } \\
\text { (HA) }\end{array}$ & $\begin{array}{l}\text { Weir \% } \\
\text { (HA) }\end{array}$ \\
\hline \multicolumn{8}{|c|}{ Parameter Group \#1 } \\
\hline \multirow{12}{*}{$\begin{array}{l}\text { Monthly } \\
\text { average } \\
\text { flow rate }\end{array}$} & January & 31.2 & $\mathrm{~m}^{3} / \mathrm{s}$ & $+10.3(\mathrm{~L})$ & $+42.2(\mathrm{M})$ & $+34.8(\mathrm{M})$ & $+83(\mathrm{H})$ \\
\hline & February & 23.0 & $\mathrm{~m}^{3} / \mathrm{s}$ & $+17.8(\mathrm{~L})$ & $+36.2(\mathrm{M})$ & $+51.5(\mathrm{M})$ & $+65.2(\mathrm{M})$ \\
\hline & March & 48.8 & $\mathrm{~m}^{3} / \mathrm{s}$ & $+13.5(\mathrm{~L})$ & $+15.4(\mathrm{~L})$ & $+21.2(\mathrm{~L})$ & $+31.2(\mathrm{~L})$ \\
\hline & April & 91.9 & $\mathrm{~m}^{3} / \mathrm{s}$ & $-2.3(\mathrm{~L})$ & $-1.7(\mathrm{~L})$ & $+7.7(\mathrm{~L})$ & $+10.4(\mathrm{~L})$ \\
\hline & May & 134.8 & $\mathrm{~m}^{3} / \mathrm{s}$ & $+5.3(\mathrm{~L})$ & $+0.8(\mathrm{~L})$ & $+9.5(\mathrm{~L})$ & $+11.5(\mathrm{~L})$ \\
\hline & June & 163.2 & $\mathrm{~m}^{3} / \mathrm{s}$ & $+10.8(\mathrm{~L})$ & $+11.8(\mathrm{~L})$ & $+8.6(\mathrm{~L})$ & $+13(\mathrm{~L})$ \\
\hline & July & 463.3 & $\mathrm{~m}^{3} / \mathrm{s}$ & $+4.5(\mathrm{~L})$ & $+6.7(\mathrm{~L})$ & $+7.4(\mathrm{~L})$ & $+14.1(\mathrm{~L})$ \\
\hline & August & 491.1 & $\mathrm{~m}^{3} / \mathrm{s}$ & $+8.7(\mathrm{~L})$ & $+16(\mathrm{~L})$ & $+7.2(\mathrm{~L})$ & $+15.1(\mathrm{~L})$ \\
\hline & September & 392.1 & $\mathrm{~m}^{3} / \mathrm{s}$ & $+4.3(\mathrm{~L})$ & $+32.6(\mathrm{~L})$ & $+10.2(\mathrm{~L})$ & $+31.7(\mathrm{~L})$ \\
\hline & October & 255.3 & $\mathrm{~m}^{3} / \mathrm{s}$ & $+0.9(\mathrm{~L})$ & $+21.8(\mathrm{~L})$ & $+4.9(\mathrm{~L})$ & $+25.3(\mathrm{~L})$ \\
\hline & November & 155.9 & $\mathrm{~m}^{3} / \mathrm{s}$ & $-3.5(\mathrm{~L})$ & $+17.9(\mathrm{~L})$ & $+3.5(\mathrm{~L})$ & $+24(\mathrm{~L})$ \\
\hline & December & 72.5 & $\mathrm{~m}^{3} / \mathrm{s}$ & $+6.1(\mathrm{~L})$ & $+28.7(\mathrm{~L})$ & $+9.3(\mathrm{~L})$ & $+39(\mathrm{M})$ \\
\hline \multicolumn{8}{|c|}{ Parameter Group \#2 } \\
\hline 1-day & nimum & 11.3 & $\mathrm{~m}^{3} / \mathrm{s}$ & $+14(\mathrm{~L})$ & $+58.5(\mathrm{M})$ & $+22.2(\mathrm{~L})$ & $+67.4(\mathrm{H})$ \\
\hline 3-day & nimum & 11.6 & $\mathrm{~m}^{3} / \mathrm{s}$ & $+14.1(\mathrm{~L})$ & $+56(\mathrm{M})$ & $+22.2(\mathrm{~L})$ & $+65.6(\mathrm{M})$ \\
\hline 7-day & nimum & 16.5 & $\mathrm{~m}^{3} / \mathrm{s}$ & $+0.9(\mathrm{~L})$ & $+28.4(\mathrm{~L})$ & $+7.1(\mathrm{~L})$ & $+37.4(\mathrm{M})$ \\
\hline 30-day & inimum & 19.1 & $\mathrm{~m}^{3} / \mathrm{s}$ & $+13.6(\mathrm{~L})$ & $+31.8(\mathrm{~L})$ & $+25.3(\mathrm{~L})$ & $+49.1(\mathrm{M})$ \\
\hline 90-day & inimum & 50.4 & $\mathrm{~m}^{3} / \mathrm{s}$ & $+6.7(\mathrm{~L})$ & $+5.7(\mathrm{~L})$ & $+24.2(\mathrm{~L})$ & $+25.2(\mathrm{~L})$ \\
\hline 1-day & ximum & 2031 & $\mathrm{~m}^{3} / \mathrm{s}$ & $+6.9(\mathrm{~L})$ & $-21.1(\mathrm{~L})$ & $+13.1(\mathrm{~L})$ & $-19.8(\mathrm{~L})$ \\
\hline 3-day & ximum & 1945 & $\mathrm{~m}^{3} / \mathrm{s}$ & $+5(\mathrm{~L})$ & $-20.3(\mathrm{~L})$ & $+9.4(\mathrm{~L})$ & $-19(\mathrm{~L})$ \\
\hline 7-day & ximum & 1711 & $\mathrm{~m}^{3} / \mathrm{s}$ & $+3.8(\mathrm{~L})$ & $-17.8(\mathrm{~L})$ & $+7.3(\mathrm{~L})$ & $-16.3(\mathrm{~L})$ \\
\hline 30-day & ximum & 960 & $\mathrm{~m}^{3} / \mathrm{s}$ & $+0.6(\mathrm{~L})$ & $-3.6(\mathrm{~L})$ & $+4.6(\mathrm{~L})$ & $-2.2(\mathrm{~L})$ \\
\hline 90-day & aximum & 703 & $\mathrm{~m}^{3} / \mathrm{s}$ & $+0(\mathrm{~L})$ & $-1(\mathrm{~L})$ & $+5.1(\mathrm{~L})$ & $+0.9(\mathrm{~L})$ \\
\hline Base & index & 0.0595 & - & $-4.6(\mathrm{~L})$ & $+19.8(\mathrm{~L})$ & $+7(\mathrm{~L})$ & $+35.8(\mathrm{M})$ \\
\hline \multicolumn{8}{|c|}{ Parameter Group \#3 } \\
\hline Date o & inimum & 49 & Julian d. & $+3(\mathrm{~L})$ & $+3.5(\mathrm{~L})$ & $+2(\mathrm{~L})$ & $+2.4(\mathrm{~L})$ \\
\hline Date o & aximum & 203 & Julian d. & $+5.3(\mathrm{~L})$ & $+5.8(\mathrm{~L})$ & $+4.7(\mathrm{~L})$ & $+5.1(\mathrm{~L})$ \\
\hline \multicolumn{8}{|c|}{ Parameter Group \#4 } \\
\hline Low $\mathrm{p}$ & e count & 4 & ea. & $+2.5(\mathrm{~L})$ & $-30(\mathrm{~L})$ & $+2.5(\mathrm{~L})$ & $-30(\mathrm{~L})$ \\
\hline Low pu & duration & 16 & $\mathrm{~d}$ & $-15.9(\mathrm{~L})$ & $+28.4(\mathrm{~L})$ & $-7.8(\mathrm{~L})$ & $+17.7(\mathrm{~L})$ \\
\hline High & e count & 5 & ea. & $+4(\mathrm{~L})$ & $-32(\mathrm{~L})$ & $+4(\mathrm{~L})$ & $-32(\mathrm{~L})$ \\
\hline High pr & duration & 7 & $\mathrm{~d}$ & $+9.3(\mathrm{~L})$ & $+72.1(\mathrm{H})$ & $+2.9(\mathrm{~L})$ & $+87.1(\mathrm{H})$ \\
\hline \multicolumn{8}{|c|}{ Parameter Group \#5 } \\
\hline & ate & 15.1 & $\mathrm{~m}^{3} / \mathrm{s}$ & $+3.7(\mathrm{~L})$ & $-28.8(\mathrm{~L})$ & $+12.2(\mathrm{~L})$ & $-26.9(\mathrm{~L})$ \\
\hline & ate & -6.2 & $\mathrm{~m}^{3} / \mathrm{s}$ & $+2.5(\mathrm{~L})$ & $-17.8(\mathrm{~L})$ & $+6.1(\mathrm{~L})$ & $-14.8(\mathrm{~L})$ \\
\hline Num. & eversals & 65 & ea. & $-2(\mathrm{~L})$ & $-32(\mathrm{~L})$ & $-5.2(\mathrm{~L})$ & $-32(\mathrm{~L})$ \\
\hline
\end{tabular}

The Future 1 results were not greatly different from the reference period when the weirs were not considered. When weirs were considered in Future 1, most parameters were changed little (L), but moderate changes $(\mathrm{M})$ arose for parameters representing dry-season discharge (January, February, 1-day and 3-day minimum), and a high change $(\mathrm{H})$ was observed for the high pulse duration. When weirs were not considered in Future 2, the overall change was greater than in Future 1 , though most parameters' changes were classified as $\mathrm{L}$, with moderate changes $(\mathrm{M})$ for January and February. In Future 2, when the weirs were considered, changes were the greatest among all scenarios studied; changes were $\mathrm{M}$ and $\mathrm{H}$ for parameters representing dry-season discharge (January $(\mathrm{H})$, February (M), December (M), 1-day minimum (H), 3-day minimum (M), 7-day minimum (M), and base flow index $(\mathrm{M})$ ), similar to Future 1 when weirs were considered. Also, the change was high for the high pulse duration.

In general, future runoff increased as a result of climate change, and in particular, the increase in runoff was much greater in Future 2 compared to Future 1. Additionally, the presence of the weirs considerably increased minimum discharge and decreased maximum discharge as shown in Table 6. 
The IHA program was used to assess the runoff characteristics more quantitatively; the results are presented in Table 7.

The monthly analysis showed that in the future, the runoff ratio of the flood season (June-September) increased by $4.3 \%-10.8 \%$ with weirs and by $6.7 \%-32.6 \%$ without weirs. The runoff ratio of the dry season (December-March) increased by $6.1 \%-51.5 \%$ with weirs and by $21.2 \%-83 \%$ without weirs. The presence of weirs led to a significant increase in the minimum discharge $(+58.5 \%$ in Future 1 and $+67.4 \%$ in Future 2 on a 1-day minimum basis) and a decrease in the maximum discharge ( $-21.1 \%$ in Future 1 and $-19.8 \%$ in Future 2 on a 1-day maximum basis). This outcome took into consideration the results of operating the weirs (the discharge of a legal in-stream flow volume) and the impacts of reservoir storage during the flood season.

Figure 8 illustrates the relative impacts of climate change and weirs on the runoff characteristics of the lower Geum River for the given reference period. For daily runoff (the average of January-December), in Future 1, the change was $+19 \%$ ( $+6.3 \%$ from climate change and $+12.7 \%$ from weirs), and in Future 2, the change was $+30.3 \%$ ( $+14.7 \%$ from climate change and $+15.6 \%$ from weirs), indicating that the weirs had a greater impact than climate change. Additionally, it was found that the increase in the 1-day minimum could be attributed to increases of $+14.0 \%$ and $+22.2 \%$ caused by climate change and increases of $+44.5 \%$ and $+45.2 \%$ caused by weirs in Future 1 and Future 2, respectively. The analysis results indicated that the impact of weirs on the runoff characteristics of the lower Geum River was also greater than that of climate change for the extreme value basis, as the decrease in the 1-day maximum was attributed to $+6.9 \%$ and $+13.1 \%$ climate change impacts and $-27.9 \%$ and $-33.0 \%$ weir impacts in Future 1 and Future 2, respectively.

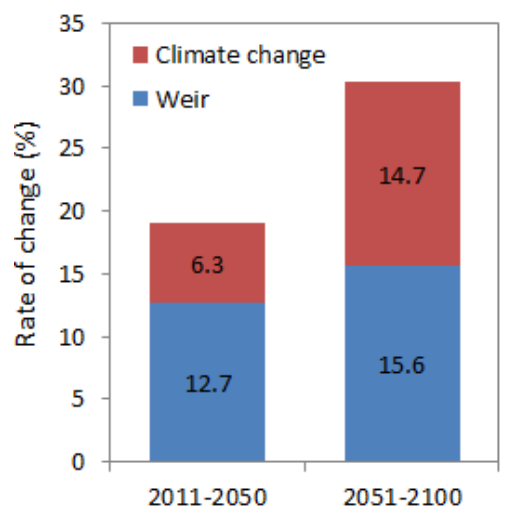

(a)

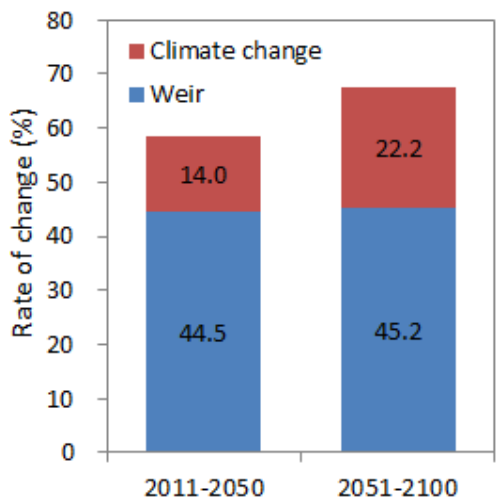

(b)

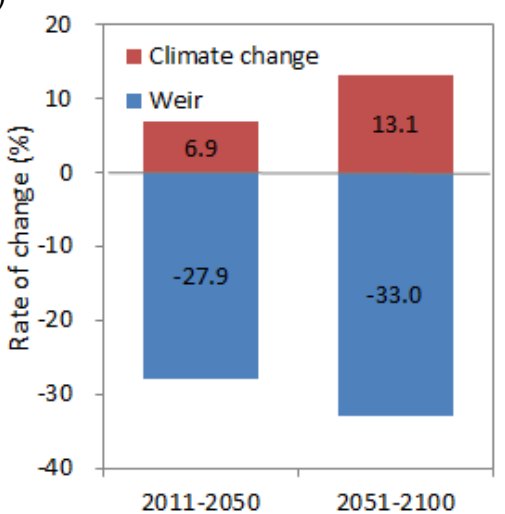

(c)

Figure 8. Impacts of climate change and weirs on future runoff characteristics of the lower Geum River. (a) Daily discharge (Average of January-December); (b) 1-day minimum; (c) 1-day maximum. 


\section{Conclusions}

The impacts of two factors on future runoff characteristics were assessed on a regional scale: the external factor of climate change and the internal factor of a large-scale water resources project. A SWAT rainfall-runoff model was built for the Geum River, where three weirs were recently constructed along the main stream. RCP climate change scenarios from the HadGEM3-RA RCM model were used to generate future climate data, and daily runoff series were constructed based on the SWAT model. The IHA program was used to carry out a quantitative assessment of the variability of runoff during two future periods (2011-2050, 2051-2100), compared to a reference period (1981-2006). Analyses of changes in the runoff characteristics of the lower Geum River showed that climate change led to an increase of the future runoff ratio and that weirs contributed to an increase in the minimum streamflow and a decrease in the maximum streamflow. The influence of the weirs on the runoff characteristics of the Geum River basin was projected to be greater than that of climate change.

This study included analyses of runoff based on the hydrological model to consider the long-term impacts of climate change. Further studies are expected in which hydrological models will be used that will more accurately reflect the hydraulic characteristics with the application of the other GCMs and RCMs, and bias correction methods; the results of this study are expected to be useful as baseline data for establishing future water resource management plans and for assessing related projects.

Acknowledgments: This work was supported by the National Research Foundation of Korea (NRF) and by a grant funded by the Korean government (MEST; No. 2011-0028564).

Author Contributions: This research presented here was carried out in collaboration between all authors. Soojun Kim and Hung Soo Kim had the original idea for the study. Huiseong Noh and Hwandon Jun conducted the research methods with Soojun Kim. Jaewon Jung contributed to make the paper from the result of the study. All authors discussed the structure and comment on the manuscript at all stages.

Conflicts of Interest: The authors declare no conflict of interest.

\section{References}

1. McCool, S.F.; Clark, R.N.; Stankey, G.H. Water and People: Challenges at the Interface of Symbolic and Utilitarian Values; United States Department of Agriculture: Portland, OR, USA, 2008.

2. Ripl, W. Water: The bloodstream of the biosphere. Philos. Trans. R. Soc. Lond. 2003, 358, 1921-1934. [CrossRef] [PubMed]

3. World Meteorological Organization (WMO). Intergovernmental Panel on Climate Change; Climate Change 2007; Synthesis Report of WMO: Geneva, Switzerland, 2007.

4. United Nations Office for Disaster Risk Reduction (UNISDR). Climate Change and Disaster Risk Reduction; The United Nations International Strategy for Disaster Reduction; UNISDR: Geneva, Switzerland, 2008.

5. Gleick, P.H. The development and testing of a water-balance model for climate impact assessment: Modeling the Sacramento Basin. Water Resour. Res. 1987, 23, 1049-1061. [CrossRef]

6. Yates, D.N.; Strzepek, K.M. Modeling the Nile Basin Under Climate Change. J. Hydrol. Eng. 1998, 3, 98-108. [CrossRef]

7. Guo, S.; Wang, J.; Xiong, L.; Ying, A.; Li, D. A macro-scale and semi-distributed monthly water balance model to predict climate change impacts in China. J. Hydrol. 2002, 268, 1-15. [CrossRef]

8. Franczyk, J.; Chang, H.J. The impacts of climate change and urbanization on the runoff of the Rock Creek basin in the Portland metropolitan area, Oregon, USA. Hydrol. Process. 2009, 23, 805-815. [CrossRef]

9. Cuo, L.; Beyene, T.K.; Voisin, N.; Su, F.; Lettenmaier, D.P.; Alberti, M.; Richey, J.E. Impacts of mid-twenty-first century climate and land cover change on the hydrology of the Puget Sound basin, Washington. Hydrol. Process. 2010. [CrossRef]

10. Purkey, D.R.; Joyce, B.; Vicuna, S.; Hanemann, M.W.; Dale, L.L.; Yates, D.; Dracup, J.A. Robust analysis of future climate change impacts on water for agriculture and other sectors: A case study in the Sacramento Valley. Clim. Chang. 2008, 87 (Suppl. S1), S109-S122. [CrossRef]

11. Obeysekera, J.; Irizarry, M.; Park, J.; Barnes, J.; Dessalegne, T. Climate change and its implications for water resources management in south Florida. Stoch. Environ. Res. Risk Assess. 2011, 25, 495-516. [CrossRef] 
12. Kim, S.; Kim, B.S.; Jun, H.; Kim, H.S. Assessment of future water resources and water scarcity considering the factors of climate change and social-environmental change in Han River basin, Korea. Stoch. Environ. Res. Risk Assess. 2014, 28, 1999-2014. [CrossRef]

13. Qiao, L.; Hong, Y.; McPherson, R.; Shafer, M.; Gade, D.; Williams, D.; Chen, S.; Lilly, D. Climate Change and Hydrological Response in the Trans-State Oologah Lake Watershed-Evaluating Dynamically Downscaled NARCCAP and Statistically Downscaled CMIP3 Simulations with VIC Model. Water Resour. Manag. 2014, 28, 3291-3305. [CrossRef]

14. Qiao, L.; Pan, Z.; Herrmann, R.B.; Hong, Y. Hydrological Variability and Uncertainty of Lower Missouri River Basin Under Changing Climate. J. Am. Water Resour. Assoc. 2014, 50, 246-260. [CrossRef]

15. Shin, J.H.; Chung, J.Y. The four major rivers restoration project in South Korea. Proc. ICE Civ. Eng. 2011, 164, 19-26. [CrossRef]

16. Davies, T.; Cullen, M.J.P.; Malcolm, A.J.; Mawson, M.H.; Staniforth, A.; White, A.A.; Wood, N. A new dynamical core for the Met Office's global and regional modeling of the atmosphere. Q. J. R. Meteorol. Soc. 2005, 131, 1759-1782. [CrossRef]

17. Martin, G.M.; Ringer, M.A.; Pope, V.D.; Jones, A.; Dearden, C.; Hinton, T.J. The physical properties of the atmosphere in the new Hadley Centre Global Environmental Model (HadGEM1). Part I: Model description and global climatology. J. Clim. 2006, 19, 1274-1302. [CrossRef]

18. Giorgi, F.; Jones, C.; Asrar, G.R. Addressing climate information needs at the regional level: The CORDEX framework. World Meteorol. Organ. Bull. 2009, 58, 175-183.

19. Panofsy, H.A.; Brire, G.W. Some application of Statistics to Meteorology; Pennsylvania State University: University Park, PA, USA, 1963; p. 224.

20. Wood, A.W.; Leung, L.R.; Sridhar, V.; Lettenmaier, D.P. Hydrologic implications of dynamical and statistical approaches to downscaling climate model outputs. Clim. Chang. 2004, 62, 189-216. [CrossRef]

21. Hashino, T.; Bradley, A.A.; Schwartz, S.S. Evaluation of bias-correction methods for ensemble streamflow volume forecasts. Hydrol. Earth Syst. Sci. 2007, 11, 939-950. [CrossRef]

22. Palmer, R.; Wiley, M.; Kameenui, A. Will Climate Change Impact Water Supply and Demand in the Puget Sound?; Department of Civil and Environmental Engineering, University of Washington: Seattle, WA, USA, 2004.

23. Durman, C.F.; Gregory, J.M.; Hassell, D.C.; Jones, R.G.; Murphy, J.M. A comparison of extreme European daily precipitation simulated by a global and a regional climate model for present and future climates. Q. J. R. Meteorol. Soc. 2001, 127, 1005-1015. [CrossRef]

24. Kyoung, M.S.; Lee, J.K.; Kim, H.S. Downscaling Technique of Monthly GCM Using Daily Precipitation Generator. Korean Soc. Civ. Eng. 2009, 29, 441-452.

25. Maurer, E.P.; Pierce, D.W. Bias correction can modify climate model simulated precipitation changes without adverse effect on the ensemble mean. Hydrol. Earth Syst. Sci. 2014, 18, 915-925. [CrossRef]

26. Cannon, A.J.; Sobie, S.R.; Murdock, T.Q. Bias Correction of GCM Precipitation by Quantile Mapping: How Well Do Methods Preserve Changes in Quantiles and Extremes? J. Clim. 2015, 28, 6938-6959. [CrossRef]

27. Maraun, D. Bias Correction, Quantile Mapping, and Downscaling: Revisiting the Inflation Issue. J. Clim. 2013, 26, 2137-2143. [CrossRef]

28. Wilby, R.L.; Dawson, C.W.; Barrow, E.M. SDSM-A decision support tool for the assessment of regional climate change impacts. Environ. Model. Softw. 2002, 17, 145-157. [CrossRef]

29. Khalil, A.F.; Kwon, H.H.; Lall, U.; Kaheil, Y.H. Predictive downscaling based on non-homogeneous hidden Markov models. Hydrol. Sci. J. 2010, 55, 333-350. [CrossRef]

30. Frias, M.D.; Zorita, E.; Fernandez, J.; Rodriguez-Puebla, C. Testing statistical downscaling methods in simulated climates. Geophys. Res. Lett. 2006, 33. [CrossRef]

31. Kilsby, C.G.; Jones, P.D.; Burton, A.; Ford, A.C.; Fowler, H.J.; Harpham, C.; James, P.; Smith, A.; Wilby, R.L. A daily weather generator for use in climate change studies. Environ. Model. Softw. 2007, 22, 1705-1719. [CrossRef]

32. Robertson, A.W.; Amor, V.M.I.; James, W.H. Downscaling of Seasonal Precipitation for Crop Simulation. J. Appl. Meteorol. Climatol. 2007, 46, 677-693. [CrossRef]

33. Arnold, J.G.; Srinivasan, R.; Muttiah, R.S.; Williams, J.R. Large area hydrologic modeling and assessment: Part I. Model development. J. Am. Water Resour. Assoc. 1998, 34, 73-89. [CrossRef]

34. Soil and Water Assessment Tool (SWAT). Available online: http://swatmodel.tamu.edu/ (accessed on 6 March 2016). 
35. Neitsch, S.L.; Arnold, J.G.; Kiniry, J.R.; Williamas, J.R.; King, K.W. Soil and Water Assessment Tool Theoretical Documentation; Texas Water Resources Institute: College Station, TX, USA, 2002.

36. Ward, A.D.; Elliot, W.J. Environmental Hydrology; Lewis Publishers, CRC Press, Inc.: Boca Raton, FL, USA, 1995.

37. Richter, B.D.; Baumgartner, J.V.; Powell, J.; Braun, D.P. A method for assessing hydrologic rate of change within ecosystems. Conserv. Biol. 1996, 10, 1163-1174. [CrossRef]

38. Richter, B.D.; Braun, D.P.; Mendelson, M.A.; Master, L.L. Threats to imperiled freshwater fauna. Conserv. Biol. 1997, 11, 1081-1093. [CrossRef]

39. Richter, B.D.; Baumgartner, J.V.; Braun, D.P.; Powell, J. A spatial assessment of hydrologic alteration within a river network. Regul. Rivers Res. Manag. 1998, 14, 329-340. [CrossRef]

40. Shin, H.S. Ministry of Land, Transport and Maritime Affairs; Construction Guidelines of Urban Flood Forecasting and Warning System: FFC-G11, Report of Research Trends; Korea Institute of Construction \& Transportation Technology Evaluation and Planning (KICTEP): Gyeonggi-Do, Korea, 2009.

41. Water Resources Management Information System (WAMIS). Available online: http://www.wamis.go.kr/ (accessed on 6 March 2016).

42. Monteith, J.L. Evaporation and the environment. In The State and Movement of Water in Living Organisms. 19th Symposia of the Society for Experimental Biology; Cambridge University Press: London, UK, 1965; pp. 205-234.

43. Gao, B.; Yang, D.; Yang, H. Impact of the Three Gorges Dam on flow regime in the middle and lower Yangtze River. Quat. Int. 2013, 304, 43-50. [CrossRef]

44. Jiang, L.; Ban, X.; Wang, X.; Cai, X. Assessment of Hydrologic Rate of Changes Caused by the Three Gorges Dam in the Middle and Lower Reaches of Yangtze River, China. Water 2014, 6, 1419-1434. [CrossRef]

45. The Nature Conservancy. Indicators of Hydrologic Rate of Change Version 7; User's Manual; The Nature Conservancy: Arlington, VA, USA, 2006.

(C) 2016 by the authors; licensee MDPI, Basel, Switzerland. This article is an open access article distributed under the terms and conditions of the Creative Commons by Attribution (CC-BY) license (http://creativecommons.org/licenses/by/4.0/). 